selection of data to support his hypotheses, but any student interested in agriculture's role in economic growth in countries well or poorly developed economically will find Stipetić's book informative and thought-provoking. And his comprehensive review and listing of literature is most useful.

\author{
Frank Orazem \\ Kansas State University
}

\title{
OSVOBOZHDENIETO NA BULGARIIA I POLITIKATA NA ZAPADNITE DURZHAVI, 1876-1878. By Khristo Khristov. Sofia: Izdatelstvo na Bulgar- skata akademiia na naukite, 1968. $256 \mathrm{pp}$.
}

In approaching a subject that is quite well covered in the existing literature, Khristov, director of the Institute of History of the Bulgarian Academy of Sciences and professor of history at the University of Sofia, apparently was inspired by a dictum of the Bulgarian Communist leader Vasil Kolarov that the liberation of Bulgaria in 1878 was the result of two factors, the military power of Russia and the national liberation movement of the Bulgarians. In his own words, he has set out to "prove" Kolarov's dictum "through an investigation of the sources and on the basis of a concrete analysis of the objective historical process." The result is a work cast in conventional monographic form validating, with the tools of scholarship, positions formulated by politicians. In addition to proving Kolarov right, it adheres to the prevalent political line that in the events of $1876-78$ only Russia stood by the side of the Bulgarians.

Despite these politically dictated premises and a rather unreadable style, the monograph has considerable merit. Based on research in Russian, British, Austrian, and Bulgarian archives, published documentary collections, memoirs, the contemporary press, and the existing literature, it adds to our knowledge of the Ambassadorial Conference at Constantinople, the diplomacy of the Russo-Turkish war, the negotiation of the San Stefano treaty, the Congress of Berlin, and the final settlement as it affected Bulgaria. Particularly useful to Khristov has been the recent three-volume collection of Russian and other documents, Osvobozhdenie Bolgarii ot turetskogo iga (Moscow, 1961-67), put together by Soviet and Bulgarian historians. The collection evidences among other things the interesting role played by the American consul-general in Constantinople, Eugene Schuyler, in making known the plight of the Bulgarians in 1876 and drafting the first constitutional document for them. The study suggests that Khristov has found some very germane documents in the archives he has searched. It is a pity that he has not chosen to append them to his monograph.

$$
\begin{array}{r}
\text { Marin Pundeff } \\
\text { San Fernando Valley State College }
\end{array}
$$

PROTSESUT NA PREODOLIAVANETO NA RELIGIIATA V BULGARIIA: SOTSIOLOGICHESKO IZSLEDVANE. Edited by Zhivko Oshavkov. Sofia: Izdatelstvo na Bulgarskata akademiia na naukite, 1968. $345 \mathrm{pp}$.

In the fall of 1962 the section on historical materialism in the Institute of Philosophy of the Bulgarian Academy of Sciences conducted a large-scale survey of 42,664 adults in Bulgaria to determine by scientific methods the degree of religious 